\title{
CONSTRUCTING MEANING IN THE SERVICE OF POWER: AN ANALYSIS OF THE TYPICAL MODES OF IDEOLOGY IN ACCOUNTING TEXTBOOKS
}

\author{
John Ferguson ${ }^{{ }^{*}}$, David Collison ${ }^{2}$, David Power ${ }^{3}$ and Lorna Stevenson ${ }^{4}$
}

1. *Corresponding Author: Lecturer in Accounting and Finance, School of Management, University of St. Andrews, Scotland, KY16 9SS, UK, Tel: + 44 (0)1334 462809, Fax: +44 (0)1334 462812, e-mail: jf60@st-andrews.ac.uk

2. Professor of Accounting and Society, School of Accounting \& Finance, University of Dundee, Scotland, DD1 4HN, UK, Tel: + 44 (0)1382 384192, Fax: + 44 (0)1382 388421, e-mail: d.j.collison@dundee.ac.uk

3. Professor of Business Finance, School of Accounting \& Finance, University of Dundee, Scotland, DD1 4HN, UK, Tel: +44 (0) 1382 384854, Fax: + 44 (0)1382 388421, e-mail: d.m.power@dundee.ac.uk

4. Senior Lecturer in Accounting and Finance, School of Accounting \& Finance, University of Dundee, Scotland, DD1 4HN, UK, Tel: +44 (0) 1382 384196, Fax: + 44 (0)1382 388421, e-mail: 1.a.stevenson@dundee.ac.uk

\section{Acknowledgements}

The authors gratefully acknowledge the financial support from the Institute of Chartered Accountants of Scotland. The authors also wish to thank Prof. Prem Sikka and the two anonymous reviewers for their insightful comments. 


\title{
CONSTRUCTING MEANING IN THE SERVICE OF POWER: AN ANALYSIS OF THE TYPICAL MODES OF IDEOLOGY IN ACCOUNTING TEXTBOOKS
}

\begin{abstract}
This paper provides an analysis of the typical modes of ideology in introductory financial accounting textbooks and training materials. Drawing on Thompson's (1990) schema concerning the typical linguistic modes through which ideology operates, this research suggests that the operation of ideology is apparent within educational accounting texts, with particular strategies being more evident than others: in particular, the strategies of universalization, narrativization, rationalization and naturalization. Given the predominantly technical nature of introductory financial accounting textbooks and training manuals, the modes of ideology identified in the texts were often quite subtle; more specifically, the ideological characteristics displayed in each of the six texts analysed were often expressions of implicit or taken-for-granted assumptions.
\end{abstract}

Keywords: Accounting education, discourse analysis, ideology, maximization of shareholder wealth, neo-classical economics, textbooks 


\section{Introduction}

In his seminal work, The Structure of Scientific Revolutions, Kuhn (1962) states that "an increasing reliance on textbooks or their equivalent [is] an invariable concomitant of the emergence of a first paradigm in any field of science". ${ }^{1}$ In this respect, textbooks are typically viewed as constituting an authorised or legitimate body of knowledge in a particular field (Apple and Christian-Smith, 1991; Crawford, 2003; Kuhn, 1962; Luke, 1997). Further, they tend to be viewed as a "delivery system of facts" as opposed to "the result of political, economic, and cultural activities, battles and compromises" (Apple and Christian-Smith, 1991, p. 1-2) ${ }^{2}$. However, as Falk Pingel (1999, p.5), director of the Georg Eckert Institute (for International Textbook Research) points out, "in addition to transmitting knowledge, textbooks also seek to anchor the political and social norms of a society". Referring to history textbooks, Pingel (1999, p.6) argues that, not only do textbooks "convey facts, but [they] also spread ideologies", which are invested with "historical legitimacy". Similarly, Crawford (2003, p.5) describes the ideological and hegemonic function that textbooks can play in education, stating, "textbooks are cultural artifacts and in their production and their use inside classrooms, confront a range of issues to do with ideology".

According to Apple and Christian-Smith (1991), it is naïve to consider the knowledge conveyed in the textbook as neutral; they argue that the knowledge which is considered most "legitimate" is often the result of complex power relations. More specifically, "what is included and excluded in textbooks really signal more profound political, economic and cultural relations and histories", and hence, a "particular 
construction of reality" (Apple and Christian-Smith, 1991, p.3). In this respect, textbooks epitomize what Raymond Williams (1989, p.58) refers to as the "selective tradition":

From a whole possible area of past and present, in a particular culture, certain meanings and practices are selected for emphasis and certain other meanings and practices are neglected or excluded. Yet within a particular hegemony, and as one of its decisive processes, this selection is presented and usually successfully passed off as "the tradition", "the significant past". What has then to be said about any tradition is that it is in this sense an aspect of contemporary social and cultural organization, in the interest of the dominance of a specific class.

The aim of this paper is to explore the ideological character of introductory financial accounting textbooks and training materials in order to gain some understanding of the way in which power is embedded in these texts. A discourse analysis of six educational financial accounting texts (three textbooks and three training manuals) is undertaken, informed by Thompson's (1990) schema concerning the typical linguistic modes through which ideology operates. The paper is structured as follows: the next section provides an overview of the literature concerned with ideological aspects of accounting, business and management textbooks; this is followed by a discussion of the methodology underpinning the current research, drawing particular attention to Thompson's (1990) concept of ideology and how it is situated within his schema. The findings from an analysis of three recommended introductory financial accounting textbooks and three accounting training manuals are then presented. The final section offers some conclusions.

\section{Accounting, Business and Management Textbooks}

Numerous criticisms of accounting education have been outlined in the extant accounting literature. In particular, concerns have been raised regarding the ideological role played by accounting education in inculcating students with a particular worldview, one which 
draws on the values and assumptions of Anglo-American capitalism³ (Gray et al., 1994; Kelly et al., 1999; Lewis et al., 1992; Loeb, 1988; 1991; McPhail, 1999; McPhail, 2001; Power, 1991; Puxty et al., 1994). Moreover, it has been argued that accounting education reproduces and sustains the notion that society's welfare is optimised as a result of individuals acting in their own economic self-interest, and that the only participants in the wealth creating process that should have their interests maximised are shareholders (Collison, 2003; Collison and Frankfurter, 2000; Collison et al. 2007; Ferguson et al., 2005; McPhail, 1999; 2001; Puxty et al., 1994). Thus, accounting students are not encouraged to consider alternative ways in which society may be organised, or to speculate upon the power asymmetries which underpin the prevalent worldview that they encounter (Chua, 1996; Gray et al., 1994; Lewis et al., 1992; McPhail, 1999; 2001; Power, 1991; Puxty et al., 1994).

Despite the emergence of these criticisms, only a handful of studies have extended their analysis to include the textbooks used in accounting degree curricula or professional accounting training. Many of these studies highlight the dominance of a neoclassical economics worldview underpinning accounting texts, and, in particular, that these texts also emphasize the interests of shareholders above all other stakeholder groups (Cuganesan et al., 1997; Ferguson et al., 2005; 2006; Kelly and Pratt, 1994; Scapens et al., 1984) ${ }^{4}$. For example, in a study of management accounting textbooks, Scapens et al. (1984, p.34) point out that the underlying assumptions of the models contained within the texts assume "that the decision maker is either the owner or shares the owner's goals" and is a profit maximiser. This observation is supported by Kelly and Pratt (1994), who note that, despite the implicit assumptions made in management accounting textbooks, 
there is a general absence of any explicit discussion of the neo-classical economic framework that informs the texts. In a more recent analysis, Cuganesan et al. (1997, p.439) argue that management accounting is presented in textbooks "in terms of its functional contribution in organizations" and excludes "consideration of its normative presuppositions and actual effects in practical contexts". Findings from these studies would suggest that, at least in the area of management accounting, the normative assumptions which underpin these texts are very rarely made explicit.

In a series of studies concerning the ideological character of accounting textbooks, Ferguson et al. $(2005 ; 2006 ; 2007 ; 2008)$ build upon prior investigations into management accounting texts. Their analyses have variously covered aspects of production (Ferguson et al., 2006; 2008), content (Ferguson et al., 2005; 2008) and use (Ferguson, et al., 2007; 2008) of texts and have considered a range of conventional accounting subject areas, including financial accounting, management accounting and financial management. Findings from this body of research support the view that accounting textbooks can be considered a form of ideology, in so far as they construct "meaning in the service of power" (Thompson, 1990, p.23). In terms of production, Ferguson et al. (2006) highlight how the contents of textbooks are the product of complex social relations where negotiations and compromises characterize the production process. However, they argue that the knowledge which is considered most 'legitimate' tends to be mandated, either directly or indirectly, by professional accounting bodies through course accreditation requirements. In this respect, the social and symbolic capital of the accounting profession drives what gets taught on accounting degree curricula, and 
publishers seek to cover this material in order to secure as many adoptions for their texts as possible.

In their content analysis of recommended introductory accounting textbooks, Ferguson et al. (2005) provide evidence of a more pronounced shareholder orientation in financial accounting and financial management textbooks, while noting that management accounting texts had a more managerial focus. In this respect, Ferguson et al. (2005) provided further support to claims made in prior studies that the primary ethical perspective conveyed to accounting students is that of financial utilitarianism ${ }^{5}$ (see Gray et al., 1994).

In a more recent analysis concerning the use of accounting textbooks, Ferguson et al. (2007) indicate that accounting educators believe that primacy is accorded to shareholders and managers within accounting textbooks and, accordingly, supplement their recommended textbooks with additional material in order to encourage students to think about wider issues (Ferguson et al., 2007). Further, they suggest that if lecturers do not take active steps to help their students to consider other stakeholder groups (and hence, other ethical perspectives) then students may be deprived of a broader insight into the study of accounting. In building upon this research, Ferguson et al. (2008) explore the perceptions of both university accounting lecturers and professional accounting tutors regarding their recommended course material. The majority of lecturers and professional tutors interviewed for their study acknowledged that discussion of stakeholders other than shareholders was extremely limited in their recommended texts. Further, while Ferguson et al. (2008) report that university lecturers tend to recommend supplementary material to incorporate wider perspectives, it was acknowledged by these lecturers that the impact of 
such material was limited because students often ignored it. In contrast to university lecturers, professional tutors tended not to supplement their training manual at all since they felt that the training manual covered all of the 'examinable material' that the student needed. Again, both studies point to this potentially limiting, and ideological, role which textbooks can play in the accounting education process.

In a study which focuses exclusively on the content of professional accounting educational material, Sikka et al. (2007, p.5) undertake a "qualitative review" of books recommended for "professional education, including those specifically written by the profession themselves". As Sikka et al. (2007, p.9) point out, "recommended books provide authoritative texts, ideas, worldviews and conceptual maps for organising and understanding the world". Despite the claims which professional accountancy bodies make regarding the "sound theoretical and practical education" which their members receive, and that the accounting education process embraces "good principles of accounting, governance and ethical conduct", Sikka et al. (2007, p.3) argue that there is insufficient discussion of theories, principles, ethics, public interest, globalisation, scandals or social responsibility in accounting textbooks in order to produce the socially reflective accountants which the profession claims to want.

The studies outlined in this section highlight how accounting, business and management textbooks often unquestionably present a particular worldview whereby the interests of ownership and management are often prioritised. Moreover, these texts fail to address or problematise the issue of power asymmetry within the context of business and management; in this respect, it is often through the silences or taken for granted 
assumptions within business and management textbooks that an ideology is maintained or projected. The following section delineates the methodology guiding this research.

\section{Methodology}

This paper analyses the content of three introductory financial accounting textbooks, as well as the introductory financial accounting study manuals specifically written for ACCA (The Association of Chartered Certified Accountants), ICAS (The Institute of Chartered Accountants of Scotland) and ICAEW (The Institute of Chartered Accountants in England and Wales). The analysis in this paper draws on a schema developed by Thompson (1990) which specifically considers the typical linguistic modes through which ideology operates. The concept of ideology has been variously used to refer to: specific kinds of beliefs, such as fascism, communism or nationalism (Eagleton, 1991); beliefs which are in some way false or which legitimate (political) power (Eagleton, 1991; Thompson, 1990); and discourse which constrains what is said or thought (Fairclough, 2003; Van Dijk, 1998; Wodak and Meyer, 2001). However, for Thompson (1990, p23), ideology has a very specific meaning: "meaning in the service of power"6.

In tracing the history of the term ideology, Thompson (1990) notes that it was first introduced by the French philosopher Destutt de Tracey in 1796 (see also, Eagleton, 1991). While the term was initially intended to describe de Tracey's "project of a new science... concerned with the systematic analysis of ideas and sensations" (Thompson, 1990, p.29), it quickly "acquired a negative sense as the ideologues were accused by Napoleon of perpetuating doctrines which were responsible for the country's misfortune"

(Thompson, 1984, p.1). This negative conception was further developed by Marx and 
Engels (1972) in The German Ideology; they used the term in a pejorative sense to criticize "the views of the Young Hegelians", including Feuerbach, Bauer and Striner (Thompson, 1990, p.34). As Thompson (1990, p.37) notes, the term ideology was to acquire "a more general role in [Marx and Engels'] characterization of social structure and historical change". According to Thompson (1990, p.37) this general role is perhaps most clearly evident in Marx's (1970) preface to A Contribution to the Critique of Political Economy where ideology is regarded as "dependent on, and derived from, the economic conditions and class relations of production". In this respect, ideology is a system of ideas which expresses the interest of the dominant class, "but represents class relations in an illusory form" (Thompson, 1990, p.37).

After Marx, Thompson (1990, p.41) notes that the concept of ideology assumed a major role within the social sciences; however, he describes how the concept became "neutralized" in different ways. The neutralization of the concept of ideology was not as the result of an explicit attempt to transform the concept, but more the outcome of “implicit generalizations” (Thompson, 1990, p.45). For example, Thompson (1990) refers to Lenin's call, at the beginning of the $20^{\text {th }}$ century, for a socialist ideology which would counter bourgeois ideology. Furthermore, Thompson (1990) claims that a similar use of the term can be found in the work of Lukacs, who also emphasised the importance of a proletariat revolution. According to Thompson (1990, p.46), when using the term ideology to refer to the ideas of any particular group within a class struggle, the "asymmetrical aspect" implicit in Marx's use of the concept is eliminated. In other words, ideology became associated with the ideas of any social group - not just the dominant group. 
In his work, Thompson (1990, p.53) seeks to "develop a new formulation of the concept of ideology rather than rehabilitating some previous conception". Broadly speaking, he distinguishes between critical conceptions of ideology (for example, Napoleon and Marx) and neutral conceptions (for example, de Tracey, Lenin, Lukacs and Mannheim). Thompson's (1990, p.55) aim is to develop a critical concept of ideology, "drawing on some of the themes implicit in earlier conceptions while abandoning others"; in short, Thompson (1990) wishes to counter the neutralization of the concept of ideology. His definition of ideology is both succinct and quite specific: "to study ideology is to study the ways in which meaning serves to establish and sustain relations of domination" (Thompson, 1990, p.56, emphasis in original). In this regard, Thompson (1990, p.51) argues that:

Ideological phenomena are meaningful symbolic phenomenon in so far as they serve, in particular social-historical circumstances, to establish and sustain relations of domination.

In other words, symbolic phenomena are not necessarily ideological, but may be deemed to be so only in so far as they serve to maintain relations of domination. Furthermore, Thompson's definition retains one negative aspect implicit in Marx's work; more specifically, while Thompson (1990, p.56) acknowledges that a feature of ideology is its role in sustaining relations of domination, he does not specify that it is essential that ideology be "erroneous or illusory". While Thompson (1990, p.56) acknowledges that symbolic forms may be ideological in so far as they obscure or misrepresent situations, he states, "these are contingent possibilities, not necessary characteristics of ideology". In this respect, Thompson (1990, p.56) maintains that the analysis of ideology is relieved of 
an "epistemological burden", since it does not require the analyst to demonstrate that a phenomenon is "in some way false".

Finally, while Marx's concept of ideology is situated within the context of class relations, Thompson's (1990) conception is framed more broadly, and includes other forms of domination, including race and gender. Developing upon the issues discussed in this section, Thompson (1990) outlines five general modes of operation of ideology. These modes are outlined and considered in more depth in the following section.

\section{Typical Modes of Operation of Ideology}

Following his "reformulation" of the concept of ideology, Thompson (1990) outlines a schema which distinguishes five general modes through which ideology can operate: legitmation; dissimulation; unification; fragmentation; and reification ${ }^{7}$. Each of these modes can be "linked with various strategies of symbolic construction" as illustrated in Table 1 below (Thompson, 1990, p.60). It is important to note that Thompson (1990) stresses a number of qualifications regarding his schema. Firstly, he acknowledges that the operation of ideology is not restricted to the five modes outlined, and that they will not necessarily operate independently of each other. It is possible that ideology will operate in other ways or that different modes will overlap ${ }^{8}$.

\section{Insert Table 1 about here}

Secondly, the strategies listed are not exhaustive, and those which are listed are not necessarily "uniquely associated" with the modes with which they have been identified. As Thompson (1990, p.60-61) notes, "the most one could say is that certain strategies are typically associated with certain modes". Thirdly, the strategies delineated 
are not necessarily ideological in themselves but rather depend "on how the symbolic form constructed by means of this strategy is used and understood in particular circumstances" - i.e. whether it serves to sustain power relations in a particular context, such as the accounting education process (Thompson, 1990, p.61).

\subsection{Legitimation}

For the first mode of operation of ideology outlined in Table 1 - legitimation, Thompson draws on sociologist Max Weber to illustrate how systematic relations of power can be established and maintained by being represented as legitimate. For Thompson, three particular strategies typify "legitimation". The first, "rationalization" refers to the "chain of reasoning" which the producer of symbolic forms employs in order to "persuade" others that existing social relations are justified (Thompson, 1990, p.61). The second strategy, "universalization", refers to the signifying of "institutional arrangements which serve the interests of some individuals ... as serving the interests of all" (Thompson, 1990, p.61). The third strategy of this "legitimation" mode of ideology, is described by Thompson (1990, p.61) as "narrativization", whereby traditions and "stories which recount the past" are presented as if "part of a timeless and cherished tradition". Furthermore, Thompson (1990, p.62) warns that these traditions may be "invented in order to create a sense of belonging to a community and to a history which transcends the experience of conflict, difference and division".

\subsection{Dissimulation}


A second mode of ideology identified by Thompson (1990) is "dissimulation", which pertains to relations of domination that may be sustained through concealment or obscurement. Thompson (1990) identifies three typical strategies within this mode. Firstly, "displacement" occurs when a term which is normally employed to "refer to one object or individual" is used "to refer to another" (Thompson, 1990, p.62). The second strategy relating to the modus operandi of dissimulation is "euphemization", whereby social relations are described in a way which elicits positive connotations. For example, the use of terms such as "restructuring" or "downsizing" to present, in a more benign or positive light, the firing of a large number of staff. The third strategy associated with dissimulation is that of "trope". Trope refers to the figurative use of language, and may include the use of synecdoche, metonymy and metaphor.

\subsection{Unification}

The third method of ideology in Table 1 is "unification", which refers to the construction of, "at the symbolic level, a form of unity which embraces individuals in a collective identity, irrespective of the divisions that may separate them" (Thompson, 1990, p.64). Two strategies typify this mode of ideology; the first is "standardization", whereby "symbolic forms are adopted to a standard framework which is promoted as the shared and acceptable basis of symbolic exchange" (Thompson, 1990, p.64). Thompson (1990) provides the example of the establishment of a national language, which engenders a sense of national identity as well as a hierarchy among the dialects within the nation state (see also, Bourdieu, 1991). The second strategy associated with the "unification" mode of ideology is that of "symbolization of unity". According to Thompson (1990), this 
strategy involves the construction of a "collective identity and identification, which are diffused throughout a group or plurality of groups" (Thompson, 1990, p.64). This may include the construction of "symbols of national unity, such as flags, national anthems, emblems and inscriptions of various kinds" (Thompson, 1990, p.64).

\subsection{Fragmentation}

The fourth modus operandi of ideology described by Thompson (1990) is that of "fragmentation". Fragmentation is the opposite of unification: instead of unifying individuals and groups in a collectivity, fragmentation refers to the division and separation of groups that "might be capable of mounting an effective challenge to dominant groups" or by "orientating forces of opposition towards a target which is projected as evil, harmful or threatening" (Thompson, 1990, p.65). One strategy associated with this mode of ideology is "differentiation", whereby "distinctions, differences and divisions between individuals and groups" are emphasised (Thompson, 1990, p.65). The second strategy of "fragmentation" is described by Thompson (1990, p.65) as the "expurgation of the other". This strategy involves the "construction of an enemy" which presents a threat and which "individuals are called upon collectively to resist or expurgate" (Thompson, 1990, p.65).

\subsection{Reification}

The final mode of operation of ideology identified by Thompson $(1990$, p.65) is "reification", and is described as the establishment of relations of domination by representing "a transitory, historical state of affairs as if it were permanent, natural, 
outside of time". Reification may be expressed in symbolic forms through the strategy of "naturalisation"; this strategy refers to the treatment of a "state of affairs which is a social and historical creation ... as a natural event or as the inevitable outcome of natural characteristics" (Thompson, 1990, p.66). For example, the institutionalization of the division of labour between men and women is often portrayed as the outcome of physiological differences (Thompson, 1990).

Another strategy associated with the "reification" mode of ideology is that of "eternalization" (Thompson, 1990, p.66). This strategy refers to social-historical phenomena which are deprived of their historical character "by being portrayed as permanent, unchanging and ever-recurring" (Thompson, 1990, p.66). Finally, reification may be expressed in symbolic forms through the strategy of "nominalization". This strategy is a grammatical device whereby "descriptions of action and the participants involved in them, are turned into nouns": for example, "the banning of imports" as opposed to "the Prime Minister has decided to ban imports" (Thompson, 1990, p.66).

\section{Ideological analysis of introductory financial accounting textbooks \& training manuals}

Thompson (1990) suggests that researchers may draw on several methods when considering the analysis of the internal structure of symbolic forms such as accounting textbooks. These include a range of discourse analytical approaches such as, semiotic analysis, narrative analysis, argumentative analysis, syntactic analysis, etc. The aim of text analysis within Thompson's framework is to consider the "articulated structure" of symbolic forms, acknowledging that they are complex constructions that "say something 
about something" (Thompson, 1990, p.284). According to Thompson (1990), the approach to discourse analysis will depend on the objects and circumstances of enquiry. For example, Thompson (1990, p.285) suggests that advertisements are particularly well suited to semiotic analysis, since many advertisements are "based on symbolic association or displacement". Similarly, argumentation analysis may be useful when considering political discourse, such as speeches from government ministers, whereby the researcher can "reconstruct and render explicit the patterns of inference which characterize the discourse" (Thompson, 1990, p.289).

For the purposes of this paper, the analysis of accounting textbooks draws on the schema developed by Thompson (1990), as outlined in Section 4. In applying this schema to the analysis of introductory financial accounting textbooks and training materials, a qualitative content analysis approach was employed (David and Sutton, 2004). This qualitative approach focuses on how language and images are used to characterize individuals and events (see also Brasier, 2002; Krippendorf, 1980). A deductive coding for the content analysis was employed, involving "the production of a list of categories by which data is to be coded prior to the collection of data itself" (David and Sutton, 2004, p.205). In this paper, Thompson's (1990) schema was used as the basis of coding prior to the analysis of the introductory financial accounting texts in this study. This "bottom-up" approach was applied in order to identify ideological modes and associated strategies within introductory financial accounting texts, and to reveal the ways in which meaning may be constructed in order to maintain asymmetrical social relations (Watson, 2003). This application of Thompson's (1990) schema reflects its use in other studies (for example, Brasier, 2002; Watson, 2003). 
The qualitative content analysis was applied to the three core introductory financial accounting textbooks recommended at a large number of university institutions (Ferguson et al. 2008), and three training manuals used by professional accounting bodies. The analysed texts are: Wood and Sangster (2005), Business Accounting 1; Black (2005), Introduction to Accounting and Finance; Britton and Waterston (2006), Financial Accounting; ACCA (2005) Preparing Financial Statements; ICAS (2005) Test of Competence: Financial Accounting; and ICAEW (2007) Accounting: Professional Stage. The recommended textbooks and training manuals were chosen for analysis since it was felt that students would predominantly engage with the recommended textbook; engagement with other supplementary recommended material would be limited ${ }^{9}$.

Analysis was undertaken by reading each of the six texts in their entirety while identifying characteristics that corresponded with Thompson's (1990) schema. A preliminary analysis of the first chapter of each of the three textbooks was undertaken independently by each of the authors; each analysis was then compared and checked for consistency. While there were a few minor discrepancies, for example, where a mode of ideology was identified within a text that could be interpreted as belonging to more than one category, the process was deemed to generate sufficient consistency for the analysis of the recommended textbooks and study manuals to continue in their entirety. The findings of the analysis will be discussed under the following five headings: legitimation; dissimulation; unification; fragmentation; and reification.

\subsection{Legitimation}

Common to all of the financial accounting textbooks and study manuals was their discussion of potential 'users' of accounting information; this discussion was generally 
contained within the introductory chapter of each text. A list of stakeholders or potential users of accounting information was identified in each text, with a very brief explanation of what each of their information requirements were likely to be. In their discussion, both Black (2005) and Britton and Waterston (2006) referred to authoritative sources: the ASB's Statement of Principles and the IASB's Framework for the Preparation and Presentation of Financial Statements respectively. In both Black (2005) and Britton and Waterston (2006), shareholders appeared first on the list in their discussion of users. For each of the professional study manuals, managers appeared first on the list, followed by owners/shareholders, while the general public were placed at the bottom of each list. One might legitimately assume that such lists were ordered in terms of the perceived relative importance of each user group and their right to financial information. Thus, the rankings of stakeholders seemed to support the neo-classical economic framework that is said to underpin accounting texts by prioritizing shareholders and managers in the lists of those for whom accounting information might be prepared. In all of the recommended textbooks and study manuals, it was assumed that users were primarily interested in financial information or the financial performance of an entity.

The strategy of legitimation which all of the texts share, to a greater or lesser extent, is the assumption of universalisation, in other words that a single set of financial statements will satisfy the user needs of all the stakeholder groups that they identify. Black's (2005) treatment of this issue differs from the other two recommended textbooks, in that the author merely lists the users and their perceived needs, providing no discussion on whether or not a single set of financial statements can possibly meet these needs. Whilst both Britton and Waterston (2006) and Wood and Sangster (2005) acknowledge 
that a single set of statements might not necessarily satisfy all user needs, the authors present a rationalisation of their preference for a single set of financial statements, based primarily on the perceived additional costs of providing information to a range of users. For example, Wood and Sangster (2005, p.7) state that:

Many different groups of stakeholders make it impossible to produce accounting information at a reasonable cost... As a result, accounting focuses on producing information for owners. The other stakeholder groups often find the accounting information provided fails to tell them what they really want to know. However, if organisations made the effort to satisfy the information needs of all stakeholders, accounting would be a very costly exercise indeed.

Similarly, Britton and Waterston (2006, p.11) also raise the question of cost, asking, "who would pay for all the extra reports if separate reports were produced for different user groups?" Although Britton and Waterston (2006) pose this question, they at no point allude to the fact that the IASB 'Framework' upon which they base their discussion explicitly states that all user needs can be adequately addressed by preparing financial statements primarily aimed at shareholders. In fact, Wood and Sangster (2005) is the only one of the three recommended textbooks to acknowledge that financial statements are prepared for 'the owners' - despite the fact that Wood and Sangster (2005) did not refer to either the IASB's 'Framework' or the ASB's Statement of Principles which make this explicit.

Like Black (2005), all three professional study manuals merely list the potential users of accounting information, implying that a single set of financial statements could adequately satisfy the user needs of each group. ICAS (2005, section 14.4) draws attention to the IASB's Framework, highlighting how the Framework maintains that the user needs of all stakeholder groups can be adequately addressed by "focusing on the needs of present and potential investors" referred to in ICAS (2005) as the "defining class 
of users". Despite the contestability of such a statement, this assumption is not problematised in any way by ICAS (2005). While ACCA (2005) discusses the ASB's Statement of Principles, there is no discussion that this conceptual framework also explicitly prioritises the user needs of shareholders. Although ACCA (2005, p.199) mentions that one of the benefits of the Statement of Principles is that it "provides a basis for resolving disputes", it is not clear what the nature of these disputes might be. If one were to assume that disputes were waged between different users of financial statements regarding their right to information, then ACCA's (2005) silence in regard to the priority ascribed to shareholders in the Statement of Principles is significant. In referring to the role of the auditor, ACCA (2005, p.287) explicitly implies that by serving the interests of shareholders, the wider interests of society are addressed, stating that by acting as a "watchdog for shareholders" auditors also serve as a watchdog for "society as a whole""

Although ICAEW (2007) discusses the information needs of a range of users at the beginning of the text, later in the text that range has been significantly narrowed. In particular, in a discussion relating to the regulatory framework for company accounts, ICAEW (2007, p.420) describe how regulation is in place to help investors and that published accounts are prepared so that "investors [can] make meaningful comparisons" - the needs of other users seem to have disappeared from the discussion.

In the opening chapters of all three recommended textbooks, the authors draw on stories which 'recount the past' when explaining the role/function of accounting. By presenting the practice of accounting "as part of a timeless and cherished tradition" (Thompson, 1990, p.61) all three texts potentially obscure relations of domination. For example, Wood and Sangster (2005, p.xv) note that: 
[Double entry] has been in common use for over 500 years and is probably the most tried and tested technique for doing anything you are likely to encounter.

Utilising the strategy of narrativisation, the three recommended textbooks mention Luca Pacioli in terms of the development of accounting. Whilst mentioning the influence of Pacioli is not necessarily ideologically charged in itself, again, none of the three texts reflect upon the immense changes which have occurred in the organisation of business activity since the $15^{\text {th }}$ century, when Pacioli's Summa was first published. In other words, although there is a need to place accounting in a historic context, by neglecting to differentiate between the structure of organisations and, in particular, between issues of ownership and control, students are led to believe that a set of techniques developed in a completely different social and economic context - in particular one where the separation of management and control did not exist - can serve the same purpose in contemporary business organisations such as multi-national corporations.

Only one of the professional training manuals, ICAS (2005), draws attention to the historical context of accounting, referring to Pacioli's Summa as well as the use of record keeping in early civilisations such as, "Babylonians, Assyrians and Egyptians". However, as with the textbooks, ICAS (2005) does not provide any suggestion of the immense changes to the structure of organisations which have taken place since these early times. It is worth noting that, while the three recommended textbooks and ICAS (2005) recount stories from the past and, arguably, place accounting within a "cherished tradition", both ACCA (2005) and ICAEW (2007) neglect to provide any historical context whatsoever. 
Britton and Waterston (2006) is the only recommended textbook to explicitly consider why employee costs are classified as an expense in the income statement as opposed to an 'asset' in the balance sheet. In their discussion, Britton and Waterston (2006) employ a chain of reasoning which, it could be argued, defends the status quo in terms of offering a rationale for the asymmetrical power relations that traditional accounting systems accord to employees and shareholders. For example, they state that because a skilled workforce cannot be

reasonably objectively measured in money terms... [It] is not an asset that you will see in the balance sheet... it does not appear because the value of the asset cannot normally be objectively quantified (Britton and Waterston, 2006, p.57, emphasis added) ${ }^{10}$.

This 'rationalisation' is taken up further on pages 62 and 63 , where the authors support their argument by drawing on the IASB's Framework. Whilst Britton and Waterston (2006) acknowledge that a key employee would meet some of the Framework's definition for the classification of an asset, in that an employee will represent a future economic benefit, they state that "the Framework also imposes the further condition that the element must also be capable of being objectively quantified".

The authors express agreement with the Framework on this matter: that the lack of objectivity should mean that employees are not classified as an asset. ACCA (2005, p.192) is the only one of the examined study manuals to address this issue, and it employs a similar, albeit a much more pithy, explanation when they state that employee costs tend not to be recorded as an asset since it is "very difficult to arrive at a value".

\subsection{Dissimulation}


As mentioned in Section 4.2, the 'dissimulation' mode of ideology refers to concealment or obscurement. Although not explicitly outlined by Thompson (1990) as an ideological strategy, one could legitimately analyze what is omitted from accounting textbooks under this mode ${ }^{11}$. Thus, while the majority of the analysis focuses on the contents of the accounting texts under investigation, there is some scope, under the mode of dissimulation, to consider what they do not include. Given that Sikka et al. (2007) and Zeff (1988) have previously highlighted the exclusion of certain issues in other accounting textbooks, the analysis of omissions in this research draws heavily on both these studies.

As Sikka et al. (2007, p.21) point out, despite recent claims made by professional bodies that reforms in accounting education will lead to the emergence of accountants who are both ethical and socially responsible, a number of key issues were absent from the accounting textbooks they analysed. More specifically: the social or organisational context of accounting; ethics and social responsibility; the 'public interest'; accounting scandals; economic theory; and the politics of accounting standard setting. Similarly, for the three recommended accounting textbooks which are the focus of one element of the present study, these issues were notable for their absence. For example, the only textbook of the three to discuss social and environmental accounting was Britton and Waterston (2006). However, this discussion could be perceived as drawing a distinction between traditional accounting and social and environmental accounting. One aspect of the discussion of social and environmental accounting is important in terms of the "selective tradition"; in a section entitled "the future of financial accounting", Britton and Waterston (2006, p.11) state, 
Nevertheless, social and environmental accounting is not only a good example of the way financial accounting changes, but is also an increasingly important topic in its own right.

What this statement fails to convey, is that the accounting profession has long resisted putting social and environmental issues on the agenda. Instead of responding positively to emerging issues, as might be inferred from Britton and Waterston (2006), the accounting profession has been reluctant to develop standards or a regulatory framework on environmental issues, and indeed could be conceived as an impediment to the development of social and environmental accounting (Mathews, 1997).

Similarly, Britton and Waterston (2006) is the only one of the three textbooks to consider the legal or political context of accounting. However, this discussion is quite limited in a number of respects; in particular, while it is noted that in countries such as France and Germany, the accounting system is rule-based, reflecting the 'Roman' system of law, there is no mention of differences in the interests served by the governance structures in these countries. More specifically, Britton and Waterston (2006) do not address the fact that the interests of shareholders, above all other stakeholder groups, are enshrined in UK company law, or that German law requires other interests to be represented at board level.

While ICAS (2005) discusses the difference between accounting regulation in 'Napoleonic' law countries and more 'laissez-faire' countries, this discussion is extremely brief, covering only one paragraph. Furthermore, this discussion does not address the interests that are served by corporate activity in these different regulatory environments. These contextual issues are not addressed at all in either ACCA (2005) or ICAEW (2007). The analysis of these texts supports Sikka et al.'s (2007) assertion, that 
there is little in accounting textbooks or study manuals to encourage students to critique the agency theory or maximisation of shareholder wealth assumptions that underpin the calculations and techniques which the texts contain. In this respect, one might have thought that by introducing the legal and political context of accounting in other countries, such a critique could have been developed. However, this was not the case.

Another issue that was curiously absent from all three textbooks and two of the training manuals was ethics. Given the number of accounting scandals in recent years, which have subsequently led to questions regarding the "poverty of accounting education", it would seem reasonable that an appropriate place to introduce the issue of ethics would be in an introductory accounting textbook (Sikka et al., 2007, p.4). While it could be argued that ethical issues tend to be left to the latter part of an undergraduate degree programme or the latter stages of training, Sikka et al. (2007) point out, there is little evidence of these issues being discussed in advanced accounting textbooks.

Drawing on Zeff (1988), none of the textbooks analysed refer to the selfinterested lobbying activity which takes place during the accounting standard setting process. Admittedly, introductory financial accounting textbooks tend not to explicitly address individual accounting standards - nevertheless, this should not prevent textbooks from at least acknowledging that the rules of accounting are the outcome of a political process, often influenced by powerful groups within society (Sikka et al., 1989).

In terms of specific strategies of dissimulation identified by Thompson (1990), these are primarily concerned with aspects of language; in particular, the figurative use of language. It is apparent that in accounting textbooks the figurative use of language is not as apparent as it might be in, for example, a political speech or Chairman's statement (see 
Amernic and Craig, 2006). However, there are a few commonplace accounting terms which are pervasive in the six texts investigated, as well as in accounting discourse in general, which could be considered to be consistent with "dissimulation" as described by Thompson (1990).

The first of these is the term 'the accounting equation' which is used in all of the recommended textbooks and study manuals to explain how the value of capital can be calculated by deducting liabilities from assets. The use of the term 'equation' in the construction of a balance sheet implies a notion of mathematical objectivity. In this sense, the positive connotations associated with the term imply that some level of mathematical objectivity applies to the balance sheet. Thus, the highly subjective nature and ordering of the items which make up the balance sheet are obscured. Furthermore, there is an element of circularity in treating what is in essence a definition as an 'equation'.

Another phrase is employed by Black (2005) and Britton and Waterston (2006) which, whilst used in the context of acknowledging the limitations of financial accounting manages, simultaneously, to project a positive image for the discipline of accounting: by referring to accounting as "not an exact science", both Black (2005, p.64) and Britton and Waterston (2006, p.x and p.51) acknowledge that the measurements and assumptions in accounting practice may vary. However, by implication, they are also stating that accounting is still a science; it is simply an inexact one. In this sense, one could argue that these texts employ the strategy of displacement, whereby the positive associations with the term science, for example, rational, logical, objective, are transferred to the practice of accounting.

\subsection{Unification}


In terms of the "unification" mode of ideology, Thompson (1990, p.64) refers to artefacts which have been adapted to a "standard framework" and are "promoted as the shared and acceptable basis of symbolic exchange". Given that accounting regulations and legal statutes govern much accounting practice in the UK, it would seem inevitable and of course readily understandable, that these would be drawn on to some extent in each of the texts. Indeed, all of the textbooks and study manuals allude to these regulations and standards, and in particular, the Companies Act 1985 and the ASB's Statement of Principles; however the study manuals draw on a wider range of accounting regulations and tend to devote more discussion to such issues. It could, of course, be argued that for sound pedagogic reasons reference to regulations should be included in an introductory financial accounting textbook. For this reason, the present analysis will not dwell on the discussion of company law or accounting standards which appear in each of the texts (although what was left out of discussions relating to regulation, for example, what Zeff (1989) refers to as 'economic consequences' issues, was considered in the previous section).

Nonetheless, other aspects of unification were apparent in the three textbooks. More specifically, the strategy of creating a collective identity, or "symbolization of unity" was employed in two of the texts. For example, Black (2005) illustrates the importance of double-entry bookkeeping by quoting from an economic correspondent of the BBC, Peter Jay. When Jay states: "Without double-entry bookkeeping capitalism itself can hardly be imagined", he alludes to a collective identity which is in no way problematised by Black. It seems to imply that the readers identify with a particular world view. Similarly, in Britton and Waterston (2006) there is another remark which 
appeals to a perceived sense of collective identity. Following a discussion of the Company Law Review in the UK, Britton and Waterston (2006, p.130) conclude that, "all of this should help maintain the UK's position as the best place to set up and run a business".

There are a number of reasons why such an assertive appeal to patriotic sentiment seems misplaced. In particular, in the preceding discussion Britton and Waterston (2006, p.130) treat the contestable as incontestable. They outline a number of features of the Company Law Review, highlighting that it will "enable better shareholder agreement", "facilitate better communications with shareholders" and "modernize and deregulate the law". Given that no reference is made to any other stakeholder group, the reader can only assume that the UK is the 'best' place to set up a business because it prioritises the interests of shareholders and emphasises free market principles. Again, this assertion is not problematised in any way, and there is no discussion of alternative governance arrangements which take into consideration the interests of other stakeholder groups.

As mentioned above, all of the professional study manuals analysed refer to accounting standards and company legislation; while this in itself is not evidence of an ideological strategy, there are a number of remarks made in these texts which could legitimately be interpreted as appeals to a collective identity. In particular, ACCA (2005) note that most countries with a "developed commercial infrastructure have limited companies... and a framework of regulators surrounding them". This remark is further clarified by acknowledging that, while regulation may be viewed by companies as "irksome", even "the USA, which is widely seen as a bastion of private enterprise" has a strict accounting framework (ACCA, 2005, p.283). 


\subsection{Fragmentation}

According to Thompson (1990), "fragmentation" can be considered to be the opposite of "unification"; instead of appealing to a collective identity, fragmentation emphasises difference from the 'other' and this may include emphasising distinctions and differences, or by presenting the 'other' as evil or harmful (Thompson, 1990).

While there was little evidence in the three recommended textbooks of presenting the 'other' as evil or harmful, there were a number of occasions where distinctions were emphasised; in particular, between accounting practice in the UK and other countries. On a number of occasions, differences were highlighted as if a statement of fact with no attempt to contextualise the differences, or to discuss their implications. Black (2005) and Britton and Waterston (2006, p.6) refer to the difference between the specification of records which are required to be kept in the UK and France. While neither Black (2005) nor Britton and Waterston (2006) offer an explanation of the differences, Britton and Waterston (2006) do invite students to ponder the differences and consider whether flexibility in the UK or comparability in France was a more desirable feature in financial reporting; they concluded, "ultimately, we get the accounting that reflects our society". However, in later sections of their book, Britton and Waterston (2006) highlight further differences between the regulatory framework in the UK and the regulatory frameworks in Germany, France, the Netherlands and China. For example, Britton and Waterston (2006, p.184, emphasis added) state that in Germany, "banks were able to force companies to provide financial information... thus there was no pressure for full public disclosure". 
Whereas Britton and Waterston (2006) previously characterize the regulatory environment in the UK as "flexible", they associate Germany with "force" and imply secrecy through a perceived lack of public disclosure. Furthermore, whilst discussing the implications of Germany being a member of the EU and, in particular, the requirement for Germany to introduce the concept of 'true and fair view' in to their company law following the EU Fourth Directive, Britton and Waterston (2006, p. 184) state that in Germany:

Accounts are still prepared in accordance with law, which according to German law will provide a true and fair view. An interesting way of interpreting true and fair!

Therefore, the reader is to assume that in the UK we have a proper understanding of true and fair - as vague and contested as such a term is - whilst implying that German law, through lack of sophistication or otherwise, does not accommodate a proper understanding of the concept.

Another example of differentiation can be inferred from the Britton and Waterston (2006) text. In a passage describing the emergence of social and environmental accounting, Britton and Waterston (2006) note that while there is increasing evidence of environmental accounting, there is much less evidence of social accounting ${ }^{12}$. The reasons they cite for this state of affairs are that environmental accounting, in many ways, is more 'objective', and that social accounting tends to be "politically charged" (Britton and Waterston, 2006, p.12). One could infer from such a statement that the status quo of financial accounting is taken for granted, and that there is more evidence of environmental accounting because, due to its perceived objectivity, it more closely resembles traditional financial accounting. Furthermore, one could argue 
that social accounting is being differentiated from traditional financial accounting because of its politically charged nature. This is problematic for two reasons: first, there is a clear insinuation that being politically motivated is negative due to its incompatibility with the 'objectivity' of the status quo. Second, and perhaps more worryingly, it implies that traditional financial accounting is not politically motivated, despite the sectional interests which it serves (Collison, 2003). The ideological strategy of fragmentation was not as apparent in the three professional study manuals.

\subsection{Reification}

One strategy of the "reification" mode of ideology, is to present "a state of affairs which is a social and historical creation... as a natural event or as the inevitable outcome of natural characteristics" (Thompson, 1990, p.66). This 'naturalization' of financial accounting is apparent in all three recommended texts, whereby the fundamental characteristics of accounting are presented as something which everyone uses in their everyday lives. For example, Wood and Sangster (2005, p.4) argue that accounting is used by people in everyday life because, "otherwise, you would not know how much money you had with you, how much you would have if you spent some of it".

This naturalisation of accounting is reinforced further, and the reader is told that "we all use accounting ideas" (Wood and Sangster, 2005, p.6). Similarly, Black (2005, p.271) explains that just as individuals need to budget, 'businesses need to budget as well'. However, whilst emphasising the apparently unproblematic and natural activity of accounting - authors are ignoring issues of scale, and the different ends to which accounting activity is used by individuals in their everyday lives in comparison with, for example, multi-national corporations. 
Another aspect of naturalization apparent in all of the textbooks and study manuals is in their assumptions regarding the distribution of wealth. For example, in the first discussion of 'profit' in their text, Wood and Sangster $(2005$, p.8) state that capital "comprises the funds invested in the business by the owner plus any profits retained for use in the business less any share of profits paid out of the business to the owner". In other words, that the profits should accrue to the owners of the business is automatically assumed - it is taken as natural. Similarly, Britton and Waterston $(2006$, p.18) state that "the profits ultimately belong not to the business, but to the owners, since the whole business belongs to them". Again, it is taken as natural that profits accrue to the owners, since they own the business. Taken together with another natural assumption, that 'businesses exist to make profit' (Wood and Sangster, 2005, p.39), the reader is left in very little doubt that businesses are run primarily in the interests of the owners/shareholders. Furthermore, this is compounded by the rationale outlined above that employee costs should be classified as an expense. In other words, businesses exist for the primary aim of making profit for the owners; indeed to make, or more specifically, to maximise profit, one must minimise costs, in other words, minimize the returns to other participants in the wealth creation process. These assumptions are exemplified by a comment made in Black (2005, p.223), where he states that the purpose of management accounting is to "to keep costs down" and "maximise profit".

Like the introductory financial accounting textbooks, all three study manuals take it as natural that 'business exists in order to make profits for its owners' (ACCA, 2005, p.4) or that "the purpose of business is to make profit for its owners" (ICAEW, 2006, 
p.10). These assumptions are further elaborated in ACCA (2005, p.202) where it is stated:

Ownership interest is the residual amount found by deducting all of the entity's liabilities from all of the entity's assets... This definition makes clear that it is the owners of a business who benefit from increases in net assets

In general, all the texts analyzed accept the subtle, taken for granted, assumptions with regard to the accounting techniques they delineate. For example, ICAEW (2006, p.417) states that the origins of management accounting go back to costing, which means "establishing the cost (and so the profit) of goods, services and operations". However, as Tinker (1980, p.147) notes, this implicit utility maximizing calculus completely ignores, among other things, the "relations of production". Further, discussion of accounting techniques, in particular, those related to cost, often exhibited an implicit agency theory dimension. For example, Wood \& Sangster (2005, p.61) state that, in order to control costs, one must "endeavour to trace costs to a person responsible for the expenditure".

Another statement in Wood and Sangster (2005) also assumes that the current business context is the outcome of a natural historical process. In the context of different organizational forms, Wood and Sangster (2005, p.576) state that limited liability companies "came into existence originally because of the growth in the size of businesses, and the need to have a lot of people investing in the business who would not be able to take part in its management". This takes for granted, or naturalizes, the notion of limited liability for shareholders which, as Bakan (2004, p.12) reminds us, has been challenged in the past on the basis of "personal moral grounds". 


\section{Conclusions}

This paper has discussed the results of an ideological analysis of three financial accounting textbooks and three professional accounting training manuals. The results suggest that there is evidence within all six texts of the typical modes of operation of ideology identified by Thompson (1990). Perhaps the most prevalent of these modes identified in each of the six texts was that of legitimation. In particular, all of the texts analysed employed the strategy of universalization, through the implicit assumption that a single set of financial statements aimed at shareholders would satisfy the needs of all user groups. Furthermore, the strategy of narrativization was prevalent, whereby each of the three textbooks, and one of the training manuals, elaborated stories which "recount" the past; in particular, the publication of Pacioli's Summa, and the importance of the invention of double entry bookkeeping to contemporary business activity and the emergence of capital are commonly related.

In addition to legitimation, another frequently employed mode of ideology in each of the texts analysed was that of reification; i.e. the presentation of a socially constructed activity as if it were natural. This was mostly apparent in how each of the texts discussed profit; in particular, each text treats the accrual of profit to shareholders/owners as natural since they "own the business". While different modes of ideology were identified within each of the texts, dissimulation and fragmentation were perhaps not as apparent as the others. Given the nature of the symbolic form under investigation, this is perhaps not a surprise; for example, one might not expect to see the figurative use of language (dissimulation) a great deal in an accounting textbook. Similarly, presenting the 'other' as 
evil or harmful is perhaps not something one would expect to find either (for example, this may be more prevalent in a history textbook or political speech). Nevertheless, a few examples of each of these modes of ideology were found in each of the six texts. In this respect, the analysis of the typical modes of ideology would suggest that certain strategies are more likely to be evident in introductory financial accounting textbooks and training manuals; in particular, the strategies of rationalization, universalization, narrativization and naturalization. Given the predominantly technical nature of introductory financial accounting textbooks and manuals, the modes of ideology identified in the texts were often quite subtle; more specifically, the ideological characteristics displayed in each of the six textbooks were often expressions of implicit or taken for granted assumptions.

In building on Thompson's (1990) schema, this paper also considered what was missing from each of the financial accounting textbooks and study manuals. As part of our analysis of "dissimulation" our findings suggests that certain key issues were not addressed by any of the six texts. In particular, the issue of ethics was absent from all three financial accounting textbooks and two of the training manuals, despite recent calls from professional accounting bodies to address ethics in the accounting curriculum. In addition, there was no discussion of the social and political context of accounting in any of the six texts. Without relating accounting practice to its wider social context, one could argue that students are prevented from critiquing or recognising that there are contestable issues relating to the function of accounting or the role it plays in society. Furthermore, by neglecting to address the social and political aspects of accounting, or issues of power, the six financial accounting texts analysed could be accused of maintaining the 
ideological status quo (Collison, 2003). In particular, by concealing such issues, each of the texts could be legitimately accused of constructing meaning in the service of power.

The analysis of accounting textbooks and training manuals in this paper has demonstrated that even texts which are often considered apolitical or merely technical may exhibit ideological characteristics - often in very subtle ways. These results may have implications for accounting educators in terms of the role their recommended textbooks play in the education process. Arguably, instructors need to introduce "alternative perspectives" into their teaching, through lectures and tutorials, in order to challenge the shareholder emphasis in accounting textbooks (see Ferguson et al., 2007). Moreover, in terms of what is "absent" from accounting textbooks, perhaps lecturers need to introduce supplementary reading material that address such matters. For publishers, one could argue that there would be pedagogical benefits in developing accounting textbooks which incorporate a number of "worldviews". However, as Thomson (2005) highlights, the field of higher education publishing is dominated by large media conglomerates with strong profit motives. In this respect, they aim to publish textbooks which they believe will maximize sales. As discussed earlier in the paper, because accounting curricula is strongly influenced by professional accounting bodies' accreditation requirements, publishers tend to publish books that cover accredited material. In this respect, one could argue that the accounting profession should take the lead in terms of developing accreditation criteria which includes wider contextual material - one would assume that the publishers would then follow. 


\section{Endnotes}

${ }^{1}$ Kuhn (1962, p.165) drew a distinction in his work between the natural sciences and the social sciences; in particular, he maintained that while the student in the natural sciences relies mainly on the textbook, in the social sciences, students are encouraged to employ "parallel readings in original sources, some [being] "classics" of the field, others the contemporary research reports that practitioners write for each other". However, it is worth noting that an "excessive reliance" on the textbook in accounting education has been frequently discussed in the extant literature (AAA, 1986, p.177). For example, according to Herring (2003, p.90), "instructors [in accounting education] have used textbooks as a crutch, with the more inexperienced teachers simply becoming textbook facilitators" (Herring, 2003, p.90).

${ }^{2}$ Given that textbooks are, according to Apple and Christian-Smith (1991), the outcome of battles and compromises over knowledge, it could be argued that textbooks provide an important site for social research - since they provide an indication of how those battles and compromises have been resolved. In many respects, it is for these reasons that Boltanski and Chiapello (2005) examine management textbooks in their analysis of contemporary capitalism.

${ }^{3}$ The authors wish to draw a distinction between what have been broadly categorised as Anglo-American models of capitalism (for example Britain and the USA) and "Rhenish" capitalism (for example, social market Europe and Japan) (Dore et al., 1999, p.102). This distinction is usually neglected in extant critiques of accounting and accounting education, which often imply that "capitalism" is a relatively monolithic and homogenous economic structure. While the Anglo-American variant is "commonly regarded as the most individualistic and libertarian of all", the Rhenish model is less driven by the capital market and exhibits a greater amount of co-operation between capital and labour (Hutton, 1996, p.258; see also, Collison, 2003; Dore, 2000; 2006; Dore et al., 1999). One specific distinction between these models is of particular significance to the arguments developed throughout this paper: that a "key" feature of Anglo-American capitalism is its "preoccupation with maximising shareholder value" (Collison, 2003, p.854). In other words, Anglo-American capitalism institutionalises the maximisation of the interests of one particular constituency in society; it is how accounting textbooks deal with such "highly contestable ideas and values", that this paper focuses upon (Collison, 2003, p.854).

4 According to Arnsperger and Varoufakis (2006) neo-classical economics is characterized by methodological individualism and methodological instrumentalism: In terms of individualism, Arnsperger and Varoufakis (2006) argue that neo-classical economics maintains "the idea that socio-economic explanation must be sought at the level of the individual agent". As Tinker et al. (1982, p.182) note, neoclassical economics expresses "a shift away from macroscopic problems... towards a microscopic emphasis on the behavior of individuals". In terms of instrumentalism, Arnsperger and Varoufakis (2006) state that neo-classical economics assumes "all behavior is preference-driven or, more precisely, it is to be understood as a means for maximising preference-satisfaction". Further, "agents' current preferences are separate from the structure of the interaction in which they are involved" (Arnsperger and Varoufakis; 2006: see also, Cooper, 1980). According to Berle (2007, p.39) neo-classical economics assumes that corporations have "the same motivations and [act] in the same way as the classical entrepreneurbusinessman" or individual agent - i.e. they are preference, or more specifically, profit driven. It is, in part, these axioms which, according to Tinker et al. (1982, p.183), maintain the neo-classical assumption "that maximizing behavior by economic agents... [leads] to the maximization of social welfare". The implausibility of this assumption, in relation to agents and markets, is succinctly and robustly addressed by Gray et al. (1996, p.17). According to Hogler and Hunt (1993, p.178), one of the most influential manifestations of a neo-classical perspective in accounting is agency theory, extensively "shaping organizational thought and research over the past decade". In this respect, "agency theory, with its emphasis on the separation of ownership and control... assumes that agents (managers) act in their own self-interest" (Hogler and Hunt, 1993, p.178). Due to the "inevitable divergence" between the interests of the principal (shareholder) and those of the agent (manager), "the principal is motivated to monitor the conduct of the agent and to provide incentives which align the agent's interests with the principal's" (Hogler and Hunt, 1993, p.178. see also Hogler and Hunt, 1990). According to Ghoshal (2005, p.80), agency theory "underlies the entire intellectual edifice in support of shareholder value maximization".

${ }^{5}$ Gray et al. (1994) assess three modes of ethical reasoning; consequentialism (of which financial utilitarianism is a subset), motivism and deontology. They argue that no particular mode is inherently superior to any other, and that it is quite often the case that individuals could apply all three. However, by emphasising one particular mode exclusively, accounting education may restrict the development of ethical reasoning. 
${ }^{6}$ Thompson's theoretical development of the concept of ideology is perhaps the most recognised aspect of his body of work; indeed, a number of studies in the area of accounting have drawn on Thompson's work in this area (Arnold, 1998; 1999; Ferguson, 2007; Ferguson et al., 2005; 2007; Francis, 1994). Ideology and Modern Culture (Thompson, 1990), builds upon his corpus in the area of ideology (in particular, Thompson, 1981; 1984).

${ }^{7}$ This study forms part of a larger analysis of the ideological characteristics of accounting textbooks, which draws on Thompson's (1990) depth-hermeneutical framework. It is important to note that Thompson's (1990) framework outlines three distinct phases, of which the formal or discursive analysis of symbolic forms (or text) is only one part. Moreover, Thompson (1990) asserts that one should not speculate upon the likely effects of texts from their analysis alone, without thoroughly investigating how these texts are interpreted by the individuals who encounter them in their everyday lives, or considering the socialhistorical contexts of text production, transmission and reception. Thompson (1990, p. 105) describes any attempt to "read off" issues regarding the production or reception of texts by attending to the text alone as the "fallacy of internalism". In this respect, the present study is limited to the typical ideological strategies found in accounting textbooks, and does not elaborate on their production or reception. A more detailed exposition of Thompson's (1990) broader framework in an accounting context can be found in Ferguson (2007). Moreover, issues concerning the ideological character of accounting textbooks in relation to their production, use and reception can be found in Ferguson et al. $(2006 ; 2007 ; 2008)$ respectively.

${ }^{8}$ The schema outlined by Thompson (1990), is echoed in a number of respects by Eagleton (1991). For example, Eagleton (1991, p.45, emphasis in original) outlines a number of strategies of ideology including, "unifying, action-orientated, rationalizing, legitimating, universalizing and naturalizing". In this sense, Eagleton (1991) explicitly delineates three of the five general modes outlined by Thompson (1990). For Thompson (1990), rationalization and universalization are strategies associated with legitimation; while the modes of dissimulation and fragmentation are not as explicitly addressed by Eagleton (1991), they are not absent from his work either. Thompson's (1990) schema forms part of a broader depth-hermenuetical framework for the analysis of ideology. Given that the present study is part of a broader analysis of accounting textbooks drawing on Thompson's (1990) framework (for example, see Ferguson, 2007; Ferguson et al., 2006; 2007; 2008) it was deemed more appropriate to employ Thompson's (1990) schema in this paper.

${ }^{9}$ Subsequent analysis confirmed that students rarely engaged with their other recommended supplementary reading material (see Ferguson et al. 2008).

${ }^{10}$ It is perhaps worth noting that, throughout their text, Britton and Waterston (2006) use the term 'objectivity' repeatedly - and the term is often employed in the context of providing a rationale for using one accounting technique over another.

${ }^{11}$ Similarly, Apple (2005) draws on Raymond Williams' (1961, p.145) concept of the 'selective tradition' to highlight the way in which education curricula are characterized by a set of "emphases and omissions". For Apple (2005, p.6), through the selection of what is considered to be "socially legitimate knowledge", education plays an important role in "distributing an effective dominant culture". Therefore, what is omitted from accounting textbooks is considered important in this regard.

${ }^{12}$ While Britton and Waterston (2006) allude to social and environmental accounting as an alternative to traditional accounting, such references are not necessarily (although they could be) constitutive of a hegemonic struggle or a counter-hegemonic discourse representing a "diffusion of culture and the spread of ideas" aimed at the emancipation of subordinate social classes (Gramsci, 1977, p.12). As Apple (1991, p.10) pointes out, textbooks need not be a complete "mirror reflection of ruling class ideas". In order to maintain its own legitimacy, the ruling power must integrate many interests, "even opposing groups under its banner" (Apple, 1995, p. 27). In describing how powerful groups may set about incorporating the views of oppositional cultures, Apple and Christian-Smith (1991) argue that one trend in textbook production is apparent; very little ever is dropped from textbooks. In this sense, "progressive items are perhaps mentioned. . . but not developed in depth" (Apple and Christian-Smith, 1991, p. 11, emphasis in original). Therefore, by simply mentioning alternative perspectives, dominant cultures can help maintain meaning in the service of power (Apple and Christian-Smith, 1991; MacIntosh, 2002; Thompson, 1990).

${ }^{13}$ While the schema was developed by Thompson (1990), Brasier (2002) applies the schema in her study of the 1996 Federal Agriculture Improvement and Reform Act in the US - the summary of Thompson's (1990) schema presented in Table 1 is derived from Brasier's (2002) study. 


\section{References}

AAA (American Accounting Association). "Future Accounting Education: Preparing for the Expanding Profession", Issues in Accounting Education, Vol.1, No.1, 1986, pp.168195.

ACCA, Preparing financial statements (Berkshire: FTC Foulkes Lynch, 2005).

Amernic, J. \& Craig, R., CEO Speak: The Language of Corporate Leadership (Montreal: McGill-Queen's University Press, 2006).

Apple, M., Ideology and the Curriculum (3e) (London: Routeledge, 2004).

Apple, M. \& Christian-Smith, L., The Politics of the Textbook (London: Routledge, 1991).

Arnsperger, C. \& Varoufakis, Y. "What Is Neoclassical Economics?", Post-Autistic Economics Review, Vol. 38, No.1, 2006, pp.2-13.

Arnold, P. "The Limits of Postmodernism in Accounting History: The Decatur Experience", Accounting, Organizations and Society, Vol. 23. No.7, 1998, pp.665-684.

Arnold, P. "From the Union Hall: A Labour Critique of the New Manufacturing and Accounting Regimes", Critical Perspectives on Accounting, Vol.10, No.4, 1999, pp.399423.

Berle, A. "The Impact of the Corporation on Classical Economic Theory", The Quarterly Journal of Economics, Vol.79, No.1, 1965, pp.26-40.

Black, G., Introduction to Accounting and Finance (Harlow: Pearson Education, 2005).

Boltanski, L. \& Chiapello, E. Le Nouvel Esprit du Capitalisme (Paris: Gallimard, 1999). The New Spirit of Capitalism, G. Elliott (trans) (London: Verso, 2005).

Bourdieu P., Language and Symbolic Power (Cambridge: Polity Press, 1991).

Brasier, K.J. "Ideology and Discourse: Characterizations of the 1996 Farm Bill by Agricultural Interest Groups", Agriculture and Human Values, Vol.19, No.2, 2002, pp.239-253.

Britton, A. \& Waterston, C., Financial Accounting (4e) (Harlow: FT Prentice Hall, 2006).

Chua, W.F. "Teaching and Learning Only the Language of Numbers: Monolingualism in a Multilingual World", Critical Perspectives on Accounting, Vol.7, No.1, 1996, pp.129156. 
Collison, D.J. "Corporate Propaganda: Its Implications for Accounting and Accountability", Accounting, Auditing and Accountability Journal, Vol.16, No.5, 2003, pp.853-886.

Collison, D.J., Ferguson, J. \& Stevenson, L.A., "Sustainability Accounting and Education", in J. Unnerman, B. O'Dwyer \& J. Bebbington (eds), Sustainability Accounting and Accountability (Oxford: Routledge, 2007).

Collison, D.J. \& Frankfurter, G.M. "Are We Really Maximising Shareholders Wealth? or: What Investors Must Know When We Do", The Journal of Investing Vol.9, No.3, 2000, pp.55-62.

Cooper, D.J. "Discussions of Towards a Political Economy of Accounting", Accounting, Organizations and Society, Vol.5, No.1, 1980, pp.161-166.

Crawford, K. "The Role and Purpose of Textbooks", International Journal of Historical Learning, Teaching and Research, Vol.3, No.2, 2003, pp.5-11.

Cuganesan, S., Gibson, R. \& Petty, R. "Exploring Accounting Educator's Enabling Possibilities: An Analysis of a Management Accounting Text", Accounting, Auditing and Accountability Journal, Vol.10, No.3, 1997, pp.432-453.

David, M. \& Sutton, C.D., Social research (London: Sage, 2004).

Dore, R. "The Important and the Unimportant in Business Education", Asian Business and Management, Vol.5, No.1, 2006, pp.9-21.

Dore, R., Stock Market Capitalism: Welfare Capitalism (Oxford: Oxford University Press, 2000).

Dore, R., Lazonick, W. \& O'Sullivan, M. "Varieties of Capitalism in the Twentieth Century", Oxford Review of Economic Policy, Vol.15, No.4, 1999, pp.102-120.

Eagleton, T., Ideology: An Introduction (London: Verso, 1991).

Fairclough, N., Analysing Discourse: Textual Analysis for Social Research (London: Routeledge, 2003).

Ferguson, J. "Analysing Accounting Discourse: Avoiding the Fallacy of Internalism", Accounting, Auditing and Accountability Journal, Vol.20, No.6, 2007, pp.912-934.

Ferguson, J., Collison, D.J., Power, D.M. \& Stevenson, L.A., An Analysis of the Role of the Textbook in the Construction of Accounting Knowledge (Edinburgh: ICAS, 2008). 
Ferguson, J., Collison, D.J., Power, D.M. \& Stevenson, L.A. "Exploring Accounting Educators' Perceptions of the Emphasis Given to Different Stakeholders in Introductory Textbooks". Accounting Forum, Vol.31, No. 2, 2007, pp.113-127.

Ferguson, J., Collison, D.J., Power, D.M. \& Stevenson, L.A. “Accounting Textbooks: Exploring the Production of a Cultural and Political Artifact", Accounting Education: An International Journal, Vol.15, No.3, 2006, pp.1-18.

Ferguson, J., Collison, D.J., Power, D.M. \& Stevenson, L.A. "What Are Recommended Accounting Textbooks Teaching Students About Corporate Stakeholders?" British Accounting Review, Vol.38, No.1, 2005, pp.23-46.

Francis, J. "Auditing, Hermeneutics and Subjectivity", Accounting, Organizations and Society, Vol.19, No.3, 1994, pp.235-271.

Ghoshal, S. "Bad Management Theories are Destroying Good Management Practices", Academy of Management Learning and Education, Vol.4, No.3, 2005, pp.75-91.

Gramsci, A., Selection from the prison notebooks (London: Lawrence and Wishart,1971).

Gray, R.H., Bebbington, J. \& McPhail, K. "Teaching Ethics and the Ethics of Teaching: Educating for Immorality and a Possible Case for Social and Environmental Accounting", Accounting Education: An International Journal, Vol.3, No.1, 1994, pp.5175.

Gray, R.H., Owen, D. \& Adams, C., Accounting and Accountability (London: PrenticeHall, 1996).

Herring, H. "Conference Address: The Accounting Education Change Movement in the United States", Accounting Education: An International Journal, Vol. 12, No.2, 2003, pp. 87-95.

Hutton, W., The State We're In (London: Vintage, 1996).

Hogler, R.L. \& Hunt, H.G. "Accounting and Conceptions of Control in the American Corporation", British Journal of Management, Vol.4, No.1, 1993, pp.177-190

Hogler, R.L. \& Hunt, H.G. "Agency Theory as Ideology: A Comparative Analysis Based on Critical Legal Theory", Accounting, Organizations and Society, Vol.15, No.5, 1990, pp.437-454.

ICAEW (Institute of Chartered Accountants in England and Wales), Accounting: Professional Stage (London: ICAEW, 2007).

ICAS (Institute of Chartered Accountants of Scotland), Test of Professional Competence: Financial Accounting (Edinburgh: ICAS, 2005). 
Kelly, M. \& Pratt, M. "Management Accounting Texts in New Zealand: The Need for a Paradigm Shift", Accounting Education: An International Journal, Vol.3, No.4, 1994, pp.313-329.

Kelly, M., Davey, H. \& Haigh, N. "Contemporary Accounting Education and Society" Accounting Education: An International Journal, Vol.8, No.4, 1998, pp.321-340.

Kuhn, T.S., The Structure Of Scientific Revolutions (Chicago: The University of Chicago Press, 1962).

Krippendorf, K., Content Analysis: An Introduction to Its Methodology (London: Sage, 1980).

Lewis, L., Humphrey, C., \& Owen, D. "Accounting and the Social: A Pedagogic Perspective”, British Accounting Review, Vol.24, No.2, 1992, pp.219-233.

Loeb, S.E. "Teaching Students Accounting Ethics: Some Crucial Issues", Issues in Accounting Education, Vol.3, No.2, 1988, pp.316-329.

Loeb, S.E. "The Evaluation of 'Outcomes' of Accounting Ethics Education”, Journal of Business Ethics, Vol.10, No.1, 1991, pp.77-84.

Luke, A. "Genres of Power: Literacy Education and the Production of Capital", In R. Hasan \& G. Williams (eds), Literacy in Society (London: Longman, 1997).

McPhail, K. "The Dialectic of Accounting Education: From Role Identity to Ego Identity", Critical Perspectives on Accounting, Vol.12, No.4, 2001, pp.471-499.

McPhail, K. "The Threat of Ethical Accountants: An Approach of Foucault's Concept of Ethics to Accounting Education and Some Thoughts of Ethically Educating for the Other", Critical Perspectives On Accounting, Vol.10, No.5, 1999, pp.833-866.

MacIntosh, N.B., Accounting, Accountants and Accountability: Poststructuralist Positions (London: Routledge, 2002).

Marx, K., A Contribution to the Critique of Political Economy (New York: International Publishers, 1970).

Marx, K. \& Engles, F., The German Ideology (New York: International Publishers, 1972).

Mathews, M.R. "Twenty-Five Years of Social and Environmental Accounting Research: Is There a Silver Jubilee to Celebrate?", Accounting, Auditing and Accountability Journal, Vol.10, No.2, 1997, pp.481-531. 
Pingel, F. UNESCO Guidebook on Textbook Research and Textbook Revision (Hannover: Verlag Hahnsche Buchhandlung, 1999).

Power, M. "Educating Accountants: Towards a Critical Ethnography", Accounting, Organizations and Society, Vol.16, No.4, 1991, pp. 333-353.

Puxty, A.G., Sikka, P. \& Willmott, H. "(Re)forming the Circle: Education Ethics and Accountancy Practices", Accounting Education: An International Journal, Vol.3, No.1, 1994, pp.77-92.

Scapens, R.W., Otley, D.T. \& Lister, R.J., Management Accounting, Organisational Theory and Capital Budgeting (London: McMillan Press, 1984).

Sikka, P., Haslam, C., Agrizzi, D. \& Kyriacou, O. "Professionalising Claims and the State of UK Professional Accountancy Education: Some Evidence", Accounting Education: An International Journal, Vol.16, No.1, 2007, pp. 3-21.

Thompson, J.B., Books in the Digital Age (Cambridge: Polity, 2005).

Thompson, J.B., The Media and Modernity: A Social Theory of the Media (Cambridge: Polity, 1995).

Thompson, J.B., Ideology and Modern Culture: Critical Social Theory in the Era of Mass Communication (Cambridge: Polity Press, 1990).

Thompson, J.B., Studies in the Theory of Ideology (Cambridge: Polity, 1984).

Thompson, J.B., Critical Hermeneutics: A Study in the Thought of Paul Ricoeur and Jürgen Habermas (Cambridge: Cambridge University Press, 1981)

Tinker, T. "Towards a Political Economy of Accounting: An Empirical Illustration of the Cambridge Controversies", Accounting Organizations and Society, Vol.5, No.1, 1980, pp.147-160.

Tinker, T., Merino, B.D. \& Neimark, M. "The Normative Origins of Positive Theories: Ideology and Accounting Thought", Accounting Organizations and Society, Vol.7, No.1, 1982, pp.167-200.

Van Dijk, T., "Critical Discourse Analysis", in D. Tannen, D. Schiffrin \& H. Hamilton (eds.), Handbook of Discourse Analysis (London: Blackwell, 1998).

Watson, G.E. "Ideology and the Symbolic Construction of Fairness in Organizational Change", Journal of Organizational Change Management, Vol.16, No.2, 2003, pp.154168.

Williams, R., The Long Revolution (London: Chatto and Windus, 1961) 
Williams, R., "Hegemony and the Selective Tradition", in, S. DeCastell, A. Luke \& C. Luke (eds), Language, Authority and Criticism: Readings on the School Textbook (London: The Falmer Press, 1989).

Wodak, R. \& Meyer, M., Methods of Critical Discourse Analysis (London: Sage, 2001).

Wood, F. \& Sangster, A., Business Accounting 1 (Harlow: FT Prentice Hall, 2005).

Zeff, S.A. "Economic Consequences in Intermediate Textbooks: A Review after Eight Years", Issues in Accounting Education, Vol.3, No.3, 1988, pp.433-445.

Zeff, S.A. "Recent Trends in Accounting Education and Research in the USA: Some Implications for UK Academics", The British Accounting Review, Vol.21, No.1, 1989, pp.159-176. 
Table 1. Modes and Associated Strategies of Ideology (Thompson, 1990)

\begin{tabular}{|c|c|c|}
\hline $\begin{array}{l}\text { Mode of operation } \\
\text { of ideology }\end{array}$ & $\begin{array}{l}\text { Linguistic } \\
\text { Strategy }\end{array}$ & Explanation \\
\hline \multirow[t]{3}{*}{ Legitimation } & Rationalization & Justify or rationalize social relations \\
\hline & Universalization & $\begin{array}{l}\text { Argues that institutional relations that serve } \\
\text { a few groups are benefiting everyone }\end{array}$ \\
\hline & Narrativization & $\begin{array}{l}\text { Current social relations are located within } \\
\text { traditions and stories from the past }\end{array}$ \\
\hline \multirow[t]{3}{*}{ Dissimulation } & Displacement & $\begin{array}{l}\text { Using a term that would normally refer to } \\
\text { something else }\end{array}$ \\
\hline & Euphemization & $\begin{array}{l}\text { Shift in descriptive language that gives } \\
\text { social relations a positive "spin" }\end{array}$ \\
\hline & Trope & $\begin{array}{l}\text { Includes synecdoche, metonymy and } \\
\text { metaphor }\end{array}$ \\
\hline \multirow[t]{2}{*}{ Unification } & Standardization & $\begin{array}{l}\text { Standardization of language and symbols to } \\
\text { create a union of individuals or groups }\end{array}$ \\
\hline & $\begin{array}{l}\text { Symbolization of } \\
\text { Unity }\end{array}$ & $\begin{array}{l}\text { Adoption of a shared set of symbols to } \\
\text { create a collective identity among groups }\end{array}$ \\
\hline \multirow[t]{2}{*}{ Fragmentation } & Differentiation & Emphasis of differences between groups \\
\hline & $\begin{array}{l}\text { Expurgation of the } \\
\text { other }\end{array}$ & $\begin{array}{l}\text { Creating a common enemy - to unite people } \\
\text { in opposition }\end{array}$ \\
\hline \multirow[t]{3}{*}{ Reification } & Naturalization & $\begin{array}{l}\text { Presenting situations as natural, and as the } \\
\text { outcome of a natural historical process }\end{array}$ \\
\hline & Eternalization & $\begin{array}{l}\text { Portraying situations without their historical } \\
\text { background }\end{array}$ \\
\hline & Nominalization & $\begin{array}{l}\text { Actors and action within a sentence are } \\
\text { turned into nouns }\end{array}$ \\
\hline
\end{tabular}

Adapted from Brasier (2002), p.241 